\title{
Upstate, Downstate, and Outstate Across the United States
}

\author{
Michael D. Sublett \\ Department of Geography, Geology, and the Environment, Illinois State \\ University, Normal, IL, USA
}

\begin{abstract}
Upstate, downstate, and outstate are informal place names, informal in that they do not have locational coordinates or defined dimensions. They are, however, useful designators for the peripheral areas of US American states with dominant urban population cores. Beginning with upstate, this study focuses on the earliest known printed uses of each peripheral term in connection with the 50 states. It looks at how core area newspapers and other critics have deprecated the rural aspect of these peripherals, leading rural residents in some states to argue against further use of the informal name. The study also reports on the results of promotional efforts to capitalize on upstate, downstate, or outstate in naming of enterprises.
\end{abstract}

KEYWORDS United States, upstate, downstate, outstate, place names, toponyms

\section{Introduction}

Frank Sinatra opened his "Songs of Sinatra" CBS radio program on 2 January I 946 by vocalizing a few lines from "Night and Day". Then he had this to say: "From Portland, M-E to Portland, O-R-E, from Key West to the Golden Gate and from downstate California to upstate New York, a very happy new year to you" (Sinatra 1946). Although he may have been reading from a prepared script, Sinatra, a Hoboken, New Jersey, native, would have grown up hearing from across the Hudson River about the differences between upstate New York and New York City. Downstate California would not have been nearly so common an expression.

George Stewart referred to place names like upstate, downstate, and outstate as "informal names". They designate places that "have no strict limits" (Stewart [1945] 2008, 377, 385). Yet upstate, downstate, and outstate have served for more than a century to help those living in metropolitan cores distinguish themselves from those who inhabit the hinterlands, and vice versa. 
The purpose of this paper is not to examine what constitutes the core and periphery of any state, as Phillips (I983) did for New York. Instead, the focus here is on (I) the earliest known printed use of the three terms for the states; (2) how they have carried negative implications for rural upstaters, downstaters, and outstaters; and (3) how businesses and organizations have appropriated these names to brand their enterprises - thus turning a peripheral put down into an areal asset.

\section{Methodology}

Finding early print dates of upstate, downstate, and outstate (UDO) was a key aspect of this project. To compile such a list, I used the commonly available free resources of Google Scholar, Google Advanced Search, and Internet Archive. I mined also library subscription databases. Among those are Academic Search Complete, African American Newspapers, America: History \& Life, American Periodicals Series Online I74I-I900, Article Search (Advanced), Chicago Tribune (I985-Present), HeinOnline Academic, Newspaper Source, Nexis Uni, Nineteenth Century US Newspapers, ProQuest Dissertations \& Theses Global, ProQuest Historical Newspapers: Chicago Defender, ProQuest Historical Newspapers: Chicago Tribune, ProQuest Historical Newspapers: The New York Times, and Westlaw. For all the databases, I looked at the 50 states three times, once each for upstate, downstate, and outstate.

Many of the earliest known UDO print uses come from Newspapers.com searches I conducted using a personal subscription. While this online source is impressive, it is not perfect. Most frustrating is the fact that some newspapers, even some major metropolitan dailies, are not currently part of the Newspapers.com database. Furthermore, the technology, especially when one is searching in the nineteenth century, returns many false positives, like upstairs instead of upstate, downstream instead of downstate, or out-of-state versus outstate.

Enterprise names are from the online Super Pages, Yellow Pages, and White Pages. Compiling enterprise names, I tried, mainly by checking enterprise websites, to ascertain if they were still in operation. Upstate Pizza is a good example of one I had to omit. It had been active in the restaurant scene of Pineville, North Carolina, in 20II; but, by late summer 20I8, this one-shop business claiming a Syracuse, New York, heritage had ceased to exist. I also avoided assigning to any state an enterprise for which the name is really a spillover from another state. Therefore, even though there is a Pennsylvania affiliate of the Upstate Niagara Cooperative, this upstate counts only for New York not for the Keystone State.

\section{Results and Discussion}

\section{Earliest Known Printed Uses}

Table I provides dates of the earliest known printed uses of UDO for each state, but I have no doubt that many entered conversations earlier than these print 
TABLE 1

DATE OF EARLIEST KNOWN PRINTED USE OF UPSTATE, DOWNSTATE, AND OUTSTATE, BY STATE

\begin{tabular}{|c|c|c|c|}
\hline State & Upstate & Downstate & Outstate \\
\hline Alabama & 9 September 1902 & 27 October 1906 & 23 February 1926 \\
\hline Alaska & 7 February 1966 & 1 December 1959 & 1997 \\
\hline Arizona & 10 March 1915 & 28 January 1915 & 8 September 1945 \\
\hline Arkansas & 12 April 1906 & 7 October 1909 & 18 November 1930 \\
\hline California & 30 April 1901 & 17 March 1910 & 8 April 1927 \\
\hline Colorado & 19 November 1903 & 8 November 1926 & 27 March 1912 \\
\hline Connecticut & 14 April 1899 & 10 April 1901 & 25 January 1945 \\
\hline Delaware & 18 August 1892 & 25 July 1881 & 10 October 1960 \\
\hline Florida & 21 July 1900 & 16 March 1909 & 4 February 1950 \\
\hline Georgia & 16 June 1909 & 8 September 1912 & 16 August 1925 \\
\hline Hawaii & 12 April 1943 & 3 August 1959 & 8 February 1970 \\
\hline Idaho & 17 February 1922 & 12 July 1912 & 2 October 1961 \\
\hline Illinois & 5 June 1903 & 3 December 1899 & 21 May 1911 \\
\hline Indiana & 8 January 1904 & 2 November 1905 & 25 February 1909 \\
\hline lowa & 25 July 1900 & 7 November 1904 & 4 November 1914 \\
\hline Kansas & 13 September 1904 & 7 June 1906 & 28 January 1909 \\
\hline Kentucky & 18 June 1901 & 28 September 1902 & 15 February 1907 \\
\hline Louisiana & 7 April 1900 & 23 May 1902 & 29 October 1927 \\
\hline Maine & 29 November 1911 & 1934 & No apparent use \\
\hline Maryland & 6 July 1907 & 17 December 1905 & 1 November 1911 \\
\hline Massachusetts & 5 December 1903 & 26 March 1917 & 8 November 1910 \\
\hline Michigan & 22 September 1900 & 12 September 1907 & 31 July 1902 \\
\hline Minnesota & 25 January 1902 & 9 March 1908 & 1 November 1914 \\
\hline Mississippi & 17 July 1904 & 29 November 1910 & 2 March 1965 \\
\hline Missouri & 10 December 1895 & 14 December 1901 & 9 November 1900 \\
\hline Montana & 30 September 1906 & 9 June 1919 & 4 November 1908 \\
\hline Nebraska & 4 March 1902 & 6 October 1907 & 17 March 1904 \\
\hline Nevada & 7 November 1906 & 22 January 1930 & 27 February 1932 \\
\hline New Hampshire & 20 June 1906 & 4 May 1923 & No apparent use \\
\hline New Jersey & 5 November 1892 & 24 May 1906 & 30 October 1928 \\
\hline New Mexico & 6 February 1913 & 15 May 1920 & 3 August 1919 \\
\hline New York & 16 January 1875 & 12 November 1891 & 13 May 1928 \\
\hline North Carolina & 24 May 1905 & 14 June 1910 & 1 October 2015 \\
\hline North Dakota & 19 April 1911 & 24 June 1904 & 5 April 1917 \\
\hline Ohio & 5 April 1862 & 8 September 1902 & 4 August 1927 \\
\hline Oklahoma & 16 April 1909 & 5 January 1910 & 23 April 1939 \\
\hline Oregon & 24 January 1907 & 23 November 1902 & 5 January 1910 \\
\hline Pennsylvania & 24 November 1899 & 15 May 1896 & 3 November 1926 \\
\hline Rhode Island & 25 August 1906 & 1963 & 22 August 1935 \\
\hline South Carolina & 12 July 1901 & 22 April 1908 & 11 August 1946 \\
\hline South Dakota & 24 June 1902 & 18 May 1910 & 3 May 1939 \\
\hline Tennessee & 29 November 1899 & 29 November 1899 & 24 August 1932 \\
\hline Texas & 15 July 1900 & 24 October 1905 & 26 October 1921 \\
\hline Utah & 7 January 1939 & 6 April 1908 & 29 November 1908 \\
\hline Vermont & 30 December 1896 & 24 July 1889 & 8 November 1988 \\
\hline Virginia & 25 April 1902 & 24 December 1920 & 25 January 1935 \\
\hline Washington & 28 September 1910 & 1 October 1919 & 24 August 1941 \\
\hline West Virginia & 15 July 1904 & 27 October 1908 & 1 October 2015 \\
\hline Wisconsin & 1 November 1900 & 28 October 1905 & 6 August 1903 \\
\hline Wyoming & 20 February 1913 & 7 February 1920 & 22 August 1928 \\
\hline
\end{tabular}

dates. "A term will exist in spoken language before it is written", said Remlinger in her study of dialect in the Upper Peninsula of Michigan (Remlinger 20I7, 57). Mencken, tracing the use of "upstate", as it referred to "New York 
State north and west of Albany", cited a printed instance from I90I as the earliest he could find, but noted the name "is probably older" (Mencken I977, 299). The Oxford English Dictionary pushes back the dates for its defined words as far as possible but features "the date of first printing" except for handwritten items like journals, and explains that some dictionaries go back farther than is comfortable for this source (OED I989, I:Xxx).

Ohio, Delaware, and Missouri account for the earliest known print dates for upstate, downstate, and outstate, respectively (Table I). Upstate Obio and downstate Delaware count among the 15 dates (out of 148 ) that occurred in the nineteenth century, 9 upstate and 6 downstate. The first print date for any outstate, Missouri, is one of I 3 I dates from the twentieth century. Outstate North Carolina and outstate West Virginia are the two twenty-first-century laggards. I am unable to provide dates for outstate Maine or outstate New Hampshire. For more than half the states, 28 of them, the date sequence of earliest printed items is first the upstate reference, next downstate, and then outstate. Massachusetts is among eight states that have an upstate item first but for which outstate then comes before downstate. Utah is the only state with a downstate-outstate-upstate sequence: April 1908 (a “down-State contemporary [minister]”) (Salt Lake Tribune I908a), November 1908 ("out-state teachers") (Salt Lake Tribune I908b), and January I939 ("upstate Utah Aggies”) (Ogden (Utah) Standard-Examiner 1939).

Somewhat surprising is the fact that so many states present a full complement of UDO, even tiny Rhode Island, a state that is smaller than a host of American counties. In 1906, a Rhode Island newspaper reported on plans for a training cruise by the USS Columbia that would necessitate sending a tender "to Providence to bring the up-State division [of the Rhode Island Naval Reserve] down the bay" where they would board the ship (Newport (Rhode Island) Mercury I906). Three decades later, a Missouri newspaper carried an editorial piece about Rhode Island politics that said, "What beat Mr. Prince was first, the terrific party split, and, second, the racial intolerance of the villagers of outstate Rhode Island" (Albany (Missouri) Ledger I935). Last, in I963, the US Army Corps of Engineers reported on their work in the Ocean State, noting, "A plan of tidal-flood protections for Narragansett and Mount Hope Bays calling for tidal barriers across East and West Passages in downstate Rhode Island ... was completed ..." (US Army. Corps of Engineers I963, 50).

Rhode Island's three references (Table I) illustrate one finding of this study: the authors of such items do not necessarily speak for the permanent residents in the affected areas. The author of the Corps piece worked out of the New England Division's Public Affairs Office, and might have been from a state where downstate is a common term. The I935 item about outstate Rhode Island appeared in a state where outstate had by the I930s long been part of the political vocabulary. Even the Newport newspaper item about upstate Rhode Island might have reflected the fact that wealthy New Yorkers often summered at Newport and would have found an upstate designation familiar as they perused their Newport newspaper. 
Diffusion of UDO terminology also could have occurred as big city news stories came to the attention of small town journalists. Across the United States, local papers often repeated news items from the New York and Chicago press, items that contained UDO references to New York, Illinois, or other states. Reading items from elsewhere, local writers could ingest what to them might have been novel and appropriate descriptive locational terms, and might have gone on to repeat them in their own writings. The Associated Press and other wire services eventually dispersed UDO terminology.

\section{Upstate}

Upstate areas typically lie north of the core areas for their states, or up the map, because we are so familiar with printed maps oriented such that north appears at the top. Actually, the top of a map can point in any direction.

Sullivan D. Harris published the first reference to an upstate area, on 5 April I 862, in an agriculturally oriented journal, Field Notes. His was also the first reference to any UDO, in this case upstate Obio. "The Cleveland and Mahoning rail-road, as our up-state readers know”, wrote Harris, "is a bully little concern, of which our worthy Governor is President and Charles Rhodes Superintendent..." (Harris I 862). He did not sign the railroad item, but the Urbana Union copied it a few days later and credited him (Urbana (Ohio) Union I 862). Born in Middlebury, Vermont, in I8 I2, Harris migrated to Ohio in 1836 , where he farmed, painted, published poetry, taught school, and wrote for farming publications. Harris did live in the northeastern corner of upstate Obio; but he could have picked up the term in travels across upstate New York, as he was once a correspondent for Moore's Rural New-Yorker (Ravenna (Ohio) Democratic Press I 877; Harris I9I I, I66).

The United States' upstate behemoth, New York, therefore, was not the first state for which a printed use of the name occurred. The earliest evidence I have found of an upstate New York item is in the I6 January I 875 issue of the New York Daily Herald wherein the writer dealt mainly with capital punishment in Queens County, which is part of New York City. "It is said that since the [ 1853 ] execution a man was hanged in one of the up-State counties who claimed to have done the deed" (New York Daily Herald I875). A decade later, The New York Times began using up-State (or similar spelling) as did the majority of New York City papers very soon thereafter, often to contrast politics of New York City with politics everywhere else in the Empire State (The New York Times I 885).

One seldom sees upstate Obio in print nowadays; but upstate New York is commonplace, appearing often in New York City papers, upstate New York papers, and elsewhere. Upstate provides New Yorkers an easy way to include, generally speaking, everything north of the primate city and its suburbs.

As a distinct area, upstate New York resonates with its residents and with outsiders. Thomas (I935) began in American Speech what became a seven-part series on pronunciation there. De Camp followed a few years later with 
"Pronunciation of Upstate New York Place-Names" (de Camp I944). Then came McDavid's "Midland and Canadian Words in Upstate New York" (McDavid I95I). There is a recognizable upstate literary tradition, which O'Donnell (I957) examined in his dissertation, “The Regional Fiction of Upstate New York", and in subsequent writing (Bergmann 1985). The area stands up as a productive entity, as in reports like The Economic Status of Upstate New York at Mid-Century (Sufrin et al. 1960). Carmer went so far as to claim "Upstate is a Country" (Carmer I966). Upstate New York surfaces in titles of nonfiction, like essayist Edmund Wilson's Upstate: Records and Recollections of Northern New York, where he discussed the pleasant summers he spent at his family homestead north of Rome, on the western edge of the Adirondacks (Wilson I97I).

Upstate sometimes takes on a darker dimension. Buckhanon called her New York novel Upstate. In it, the incarcerated protagonist, Antonio, said, "I wonder what would have happened if I would have never been sent upstate" (Buckhanon 2005). Attica, Sing Sing, and other notable New York prisons are up the map from New York City. The slang use of upstate as a surrogate for prison has traveled at least as far as neighboring Massachusetts. In the case of Commonwealth v. Carlos Vazquez, according to a police officer, Vazquez would not reveal the name of an acquaintance, stating instead, "I'm not going to say. I'll go upstate before I give his name" (Commonwealth v. Carlos Vazquez 2009).

Figure I summarizes, by decade, the earliest known upstate references in print for the 50 states. After Ohio in the I860s and New York in the I870s, came Pennsylvania in the $\mathrm{I} 880$ os and six more states in the I 890 , mainly also in the

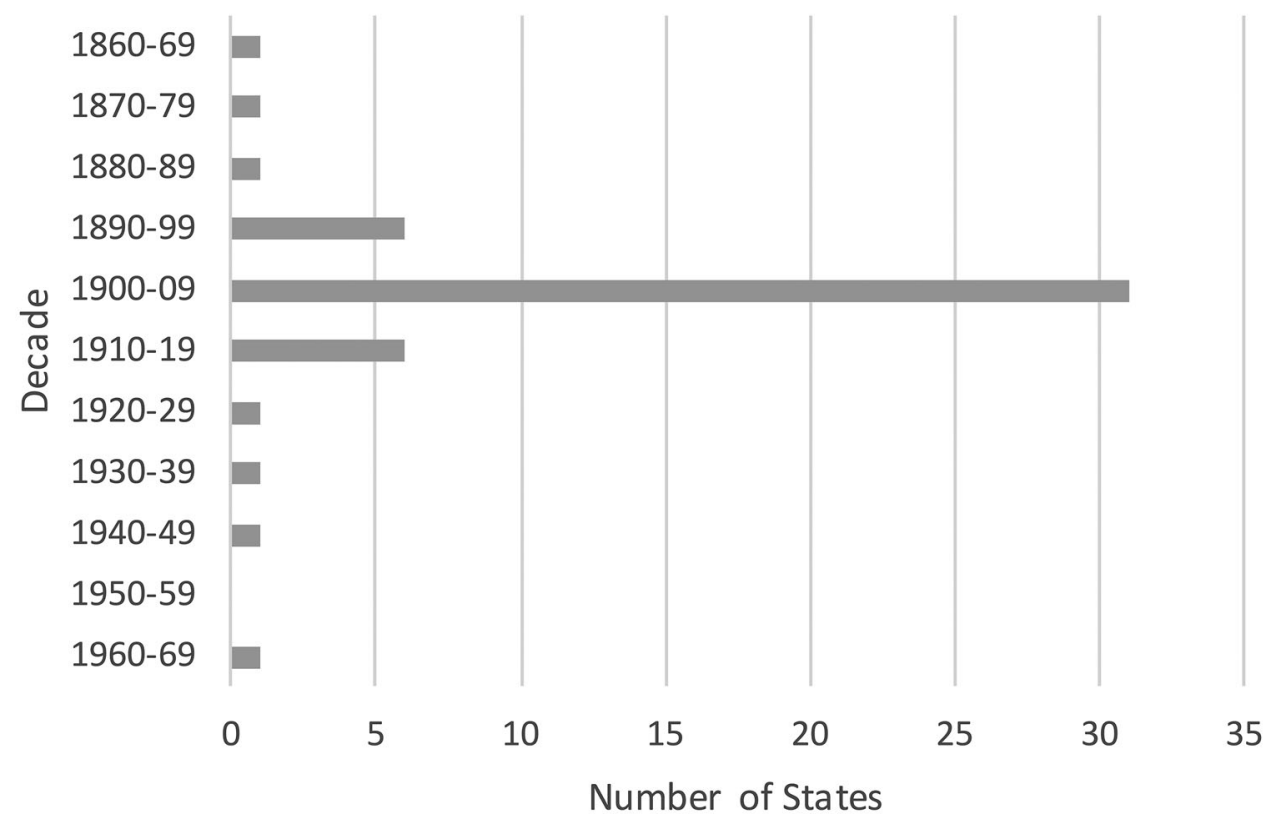

FIGURE 1. Upstate: Earliest known printed use of the name to designate a portion of a particular state, by decade. Note: Median year for upstate is 1903; modal year is 1900. 
Northeast, perhaps because of a copy-cat influence that upstate New York was having on nearby New Jersey, Connecticut, Vermont, and Delaware. Missouri and Tennessee also joined the upstate roster before the turn of the century; and the term went nationwide in the decade I900-1909, bringing 3 I more states into the fold. Three states, Oklahoma in I909 (statehood in I907), New Mexico in I9I3 (in I9I2), and Arizona in I9I5 (in I9I2), each generated a printed upstate reference soon after gaining statehood. Hawaii, however, jumped the statehood gun by I6years. In I943, the Honolulu Advertiser carried a story about US American soldiers playing baseball in Hawaii while stationed there during World War II. The writer, also a warrior and very likely from somewhere other than Hawaii, said the Infantry Appleknockers, "the Up-State boys", held off a rally by the Engineer Marauders to win 3-2 (Vandergrift I943). Hawaii did not become a state until 1959. Print reference to upstate Alaska, also a state since 1959, did not begin until I966 (Seibel I966).

No state has a bigger upstate reputation than New York, but upstate South Carolina is not that far behind. South Carolina was among the first 20 states to have a print reference to an upstate area and today can claim more upstatebranded enterprises than New York. South Carolina divides nicely into three rather equal areas: low country, midlands, and upcountry or upstate. The state's upstate is up the map, north and west of Charleston and Columbia (the capital); and it lies in the highest part of the Palmetto State, along the Piedmont edge of the Appalachian Highlands. At Spartanburg, in the middle of the upcountry, is the University of South Carolina Upstate. Early on references to South Carolina's upstate included the definitive article as did the first known printed item, on I2 July I90I: Gaffney "is one of the most prosperous and progressive towns in the up-State country" (Gaffney (South Carolina) Ledger I90I). Eventually, the country portion dropped out, as in this 7 July I9I I item: “The Governor left for the Up-State at 8 o'clock, where he will make an address tomorrow” (Newberry (South Carolina) Weekly Herald I9II). Now South Carolina references are not uncommonly to just the (or The) Upstate. Hess found definite articles common in Spanish toponyms, perhaps because of the Arabic influence, but "rare in English toponyms" (Hess I987, I8). Among the many contemporary South Carolina enterprises using the definite article are Awnings of the upstate and Pediatric Massage of the Upstate. The upstate for New York enterprises, however, is a rarity.

California, more than 700 miles north to south, seems like a logical locale for a vigorous upstate-downstate scenario. Such is not the case; but in $200 \mathrm{I}$, the northernmost 20 California counties launched an Upstate California marketing campaign to differentiate themselves from the San Francisco area and the nearby Napa-Sonoma wine country. The idea, said Robert Berry, the campaign's president, was "to bring the cachet of upstate New York" (Brown 200I). Both the Upstate California Economic Development Council and a similar campaign, Upstate Colorado Economic Development, serving Greeley and Weld County (Dunn 2006), are still active today. 
Having lunch one day at the Zenith Athletic Club with fellow business types, George Babbitt, in the words of novelist Sinclair Lewis, was listening to Sydney Finkelstein pontificate about how the most expensive product one can afford is always the best option. Finkelstein's forebears would never agree, said Finkelstein, because "they live in one of these hick towns up-state and they simply can't get onto the way a city fellow's mind works..." (Lewis I922, 57). Babbitt appeared several years after New York City newspapers and others began making fun of upstate New Yorkers, sometimes referring to their areas as "hayseed districts" (Adam I908). According to a piece that a Kansas editor reprinted, the New York Post, in 1902, claimed a recently married woman "from upstate" asked her neighbor how to kill the crabs that her husband sent home for dinner; she had been trying to drown them to no avail (St. Paul (Kansas) Journal I902). A “New Yorker" joshed an "up-state friend", telling him that the things sticking out the sides of a partially complete skyscraper in the city were "the mile posts" (Chicago Daily Herald I908). Many years after the New York City press quit mocking their upstate neighbors, Ellis opined that the "growth of suburbia leads one to believe that the typical and most influential New Yorker of the future will be neither a 'hick' nor a 'city slicker'. Rather it will be a suburbanite" (Ellis I959, 219). Such an ending to negativity has not been the case, however. Robin Lakoff, a native of New York City and then a linguistics professor, told The New York Times in 200I that upstate New York was "the sticks" to her. "It's the place you had to study in eighth grade" (Brown).

Denizens of the nation's upstates eventually realized an advantage might accrue to them if they countered the negativity by naming businesses and organizations after these peripheral areas. A recent review of that practice revealed more than a thousand upstate enterprises, in 2 I different states (Table 2). More than half of the states in the upstate column have only one upstate enterprise, like Arizona's Upstate Detailing, Connecticut's Upstate Family Dental Health, and Tennessee's Upstate Towing and Trucking. A handful of states present numbers that range from the two of New Jersey to California's ro (which includes the previously mentioned Upstate Development Council). In a different league for the upstate column, however, are New York, with 520 enterprises (from Ace Home Inspections of Upstate New York to Zimmer Upstate New York), and South Carolina, with 536 (from 360 Painting upstate South Carolina to Window World of the Upstate).

\section{Downstate}

We know not the name of the writer who first used downstate in a reference to Delaware in I88I (Table I). The item containing it was a catchall for tidbits of information: the apple crop in Kent County, the pier at Lewes, smallpox in Little Creek Landing, and an observation that it was "wonderful how the Western correspondents of some of the down-State papers pick up gall enough to sign their effusions 'Dom Pedro' (Wilmington (Delaware) Morning News 
TABLE 2

ENTERPRISES USING UPSTATE, DOWNSTATE, OR OUTSTATE IN THEIR NAMES, IN THE SUPER PAGES, YELLOW PAGES, OR WHITE PAGES, AUGUST-SEPTEMBER 2018

\begin{tabular}{llll}
\hline State & Upstate & Downstate & Outstate \\
\hline Alabama & 1 & 1 & \\
California & 10 & \\
Colorado & 1 & 3 \\
Connecticut & 1 & 10 \\
Delaware & 1 & \\
Florida & 6 & \\
Georgia & 5 & \\
Illinois & 3 & \\
Indiana & 1 & \\
Maine & 1 & \\
Maryland & 1 & \\
Michigan & 1 & \\
Minnesota & 2 & \\
New Jersey & 520 & \\
New York & 5 & \\
North Carolina & 5 & \\
Pennsylvania & 1 & \\
Rhode Island & 536 & \\
South Carolina & 1 & \\
Tennessee & 3 & \\
Texas & 1 & \\
Washington & & \\
\hline
\end{tabular}

I88I). The Dom Pedro reference has lost relevance over time, but the downstate aspect is clear. Downstate Delaware still resonates today in, among others, the downstate Delaware Striders and Riders, a fitness association headquartered in Dover.

Delaware was not the only state to achieve downstate print mention in the I 88 os (Figure 2). Another north-south state, Vermont, joined the downstate roster in 1889 , in a piece about summer fairs (Montpelier Vermont Watchman ı 889). By ı900, New York, Pennsylvania, Tennessee, and Illinois were onboard. Downstate New York popped up very early, as an upstate Buffalo paper reported on a crime in the White Plains area, which is a suburb of New York City (Buffalo Evening News I891). During the decade 1900-1909, 23 more states saw their first downstate print use. Again, Hawaii got a head start on statehood, this time by a matter of days (3 August versus 2 I August 1959). An editor in downstate Illinois, knowing that locals there would understand what it meant to be part of the periphery, thought it timely to say, "The veteran political writers are scratching their chins over the problem of what constitutes downstate Hawaii" (Decatur Herald I959). To my knowledge, downstate Hawaii has never warranted a locational definition nor has the designation ever surfaced again.

While "being sent upstate" carries a negative meaning, "playing downstate" at season's end resonates among Illinois high school athletes and their followers in a positive way, because the state tournaments in most sports are south and 


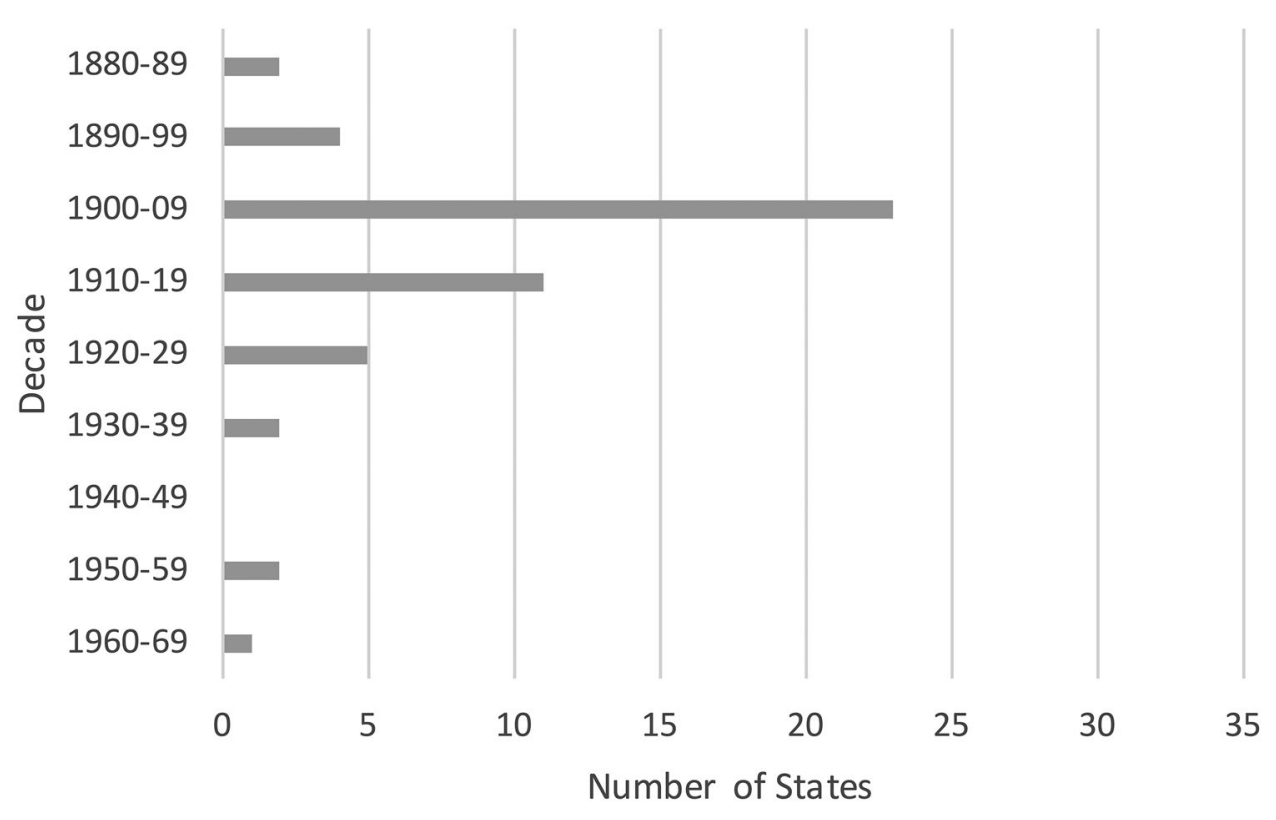

FIGURE 2. Downstate: Earliest known printed use of the name to designate a portion of a particular state, by decade. Note: Median year for downstate is 1908; modal year is 1910 .

west of Illinois's northeastern core, at places like Peoria and Charleston. Coaches, players, and fans in Chicagoland talk about going downstate as if it were the ultimate outcome of a successful season, which it most likely will be (Sublett 2016, 300). At Northridge Preparatory School in the northern Chicago suburb of Niles, for example, Forest Moses qualified for state in the high jump. "Although he wasn't able to make it to the finals ... his ability just to get down state has people at his school amazed", said a Chicago Tribune reporter (Vorva 20I3).

Downstaters have not escaped negativity at their expense. There was the future governor of Connecticut belittling a "down-state veterinary surgeon" for grossly underestimating the actual number of known germs (Hartford Courant I90I). Later that year a northern Missouri paper reprinted a notice from "A certain down-state paper" that had explained an omission as follows: "Owing to lack of space a number of births and deaths had to be postponed until the next issue" (Macon Republican I90I). In 1909, a Mrs. Dexter, "from somewhere 'down-state' was enjoying her first ride in a crowded street car in Chicago". When a police officer explained to her that the health department official onboard was sampling air quality, she declared the next thing would be a scheme to "can the air and sell it" (Yorkville Enquirer 1909). Pupil John "came from downstate to the city schools" of Indianapolis. His mother objected to classes in physical education and music as a waste of time. "He inherits whittleing [sic] from his father", she wrote the school, "and his brains from me. I'm paying to educate him, so educate his brains" (Newport (Rhode Island) Mercury I92I). 
Downstate shows up in Table 2 , as the online phonebooks revealed 32 downstate enterprises in four states. Among them are downstate Insurance Company (California), Downstate Discount Brokerage (Florida), and downstate Illinois Spine Center. The I 8 downstate enterprises in New York, several of which are medically related (like SUNY Downstate Medical Center and the Downstate Mental Hygiene Association, illustrate an effort to play off of the dominant upstate usage.

\section{Outstate}

American Speech noted that university students from Nebraska, Iowa, Colorado, and Wyoming were reporting "out-state" use among their acquaintances, with reference to "out in the state away from the main city, and out in the state away from the speaker's home" and cited its frequent appearance in the Denver Post (C. B. A. I93I, 3IO-II). Outstate still stands tallest in the heartland of the USA, places like Missouri, Minnesota, Nebraska, and Michigan. It has appeared, however, at least once in print with reference to all but two of the 50 states (Table I).

Graphs of the first known uses for upstate (Figure I) and downstate (Figure 2) resemble classic bell curves: a few early states, a few laggards, and many toward the middle of the pack. The outstate distribution (Figure 3), on the other hand, skews strongly to the earliest years, with nine instances in each of the first two decades of the twentieth century and ro in the third decade, which includes both the median year, 1927, and the modal years, 1927 and I928. The list then tails off toward the present, with North Carolina and West Virginia finally appearing in 2015. Hawaii's first outstate reference came I I years after statehood in an advertisement for an opportunity to own a vehicle rustproofing franchise. "Only eight areas available in Honolulu market. A few selected areas [are] still available outstate” (Honolulu Advertiser I970).

Missouri recorded the initial print usage of outstate, in a I900 post-election editorial that said in part, "out state Republicans" should be sore about some aspects of St. Louis politics but not about others (Marshall (Missouri) Republican I900). Outstate is a good word choice for Missouri political conversations because there has long been a divide between the rural-dominated interior and the twin cores of St. Louis and Kansas City, one centrally located on the eastern boundary and the other on the western. The author of a syndicated piece out of Los Angeles put it this way: "Outside the big cities, the political climate shifts. This is what locals call 'outstate' Missouri: a landscape of cattle pastures, soy fields, wineries and one-block towns" (Simon 2004).

Michigan was the second state with a print reference to outstate. The Detroit Free Press said, as a gubernatorial possibility, Thomas J. Cavanaugh, from rural Paw Paw, was not doing much to promote his candidacy, though "his out-state admirers" were saying he would be formidable "should the lightning strike him" (Detroit Free Press I902). Detroit and its Wayne County lie in the extreme southeastern corner of Michigan, so upstate could easily be the preferred 


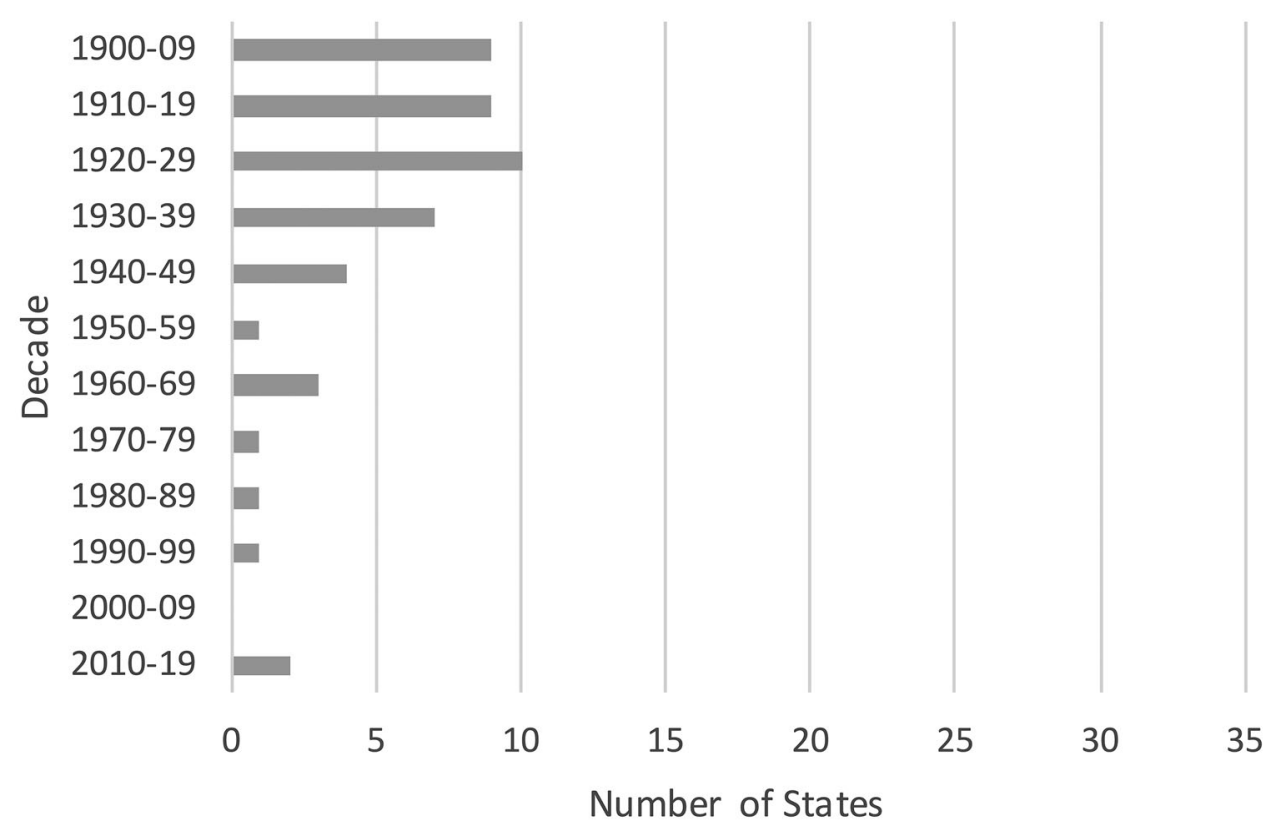

FIGURE 3. Outstate: Earliest known printed use of the name to designate a portion of a particular state, by decade. Note: Median year for outstate is 1927; modal years are 1927 and 1928. Maine and New Hampshire present no known printed uses of outstate.

peripheral. It is not. A quick search in Newspapers.com for "upstate Michigan" and "outstate Michigan" showed that the Free Press between I 837 and 2019 published nearly four times as many outstate references to Michigan as it did for upstate $(33,430$ versus 8,889$)$.

Minnesota has a centrally positioned eastside core, the Twin Cities, so upstate and downstate do not capture the layout of the Minnesota rural periphery as well as outstate. In fact, when the Minnesota legislature codified the metro area in 1967 by naming seven core counties to constitute the Metropolitan Council, it became even more logical for writers to label the other 80 counties as outstate, which they regularly do. The first known outstate Minnesota print item did not appear until I November I9I4, after I4 states had preceded it. That initial item concerned the Minneapolis post office clearing out hundreds of thousands of "pieces of political mail" with some going to "sub stations for city delivery" and the rest going "to afternoon trains for out-state delivery" (Minneapolis Star Tribune I9I4). Minnesota records today the only outstate-branded enterprise in the country, Outstate Data, an agricultural equipment business in Elbow Lake, near the North Dakota line (Table 2).

Outstate areas never generated much in the way of so-called "hicksville humor". They did, however, generate serious efforts by some outstaters themselves to eliminate outstate as an expression.

In Nebraska, a debate started when Doug Bernard, the manager of the McCook Elks Club, picked up an award for having created the best restaurant 
promotional advertising literature in "Outstate Nebraska". Bernard complained to the McCook Daily Gazette about the outstate labeling. Editor Allen Strunk agreed and wrote an editorial that said, "'Outstate Nebraska' sounds like a section of the state that was sawed off and is out there floating around. It could easily be interpreted as denoting a second rate part of the state". Maybe "Greater Nebraska" was a better choice (Beatrice (Nebraska) Daily Sun I978). Then the Outstate Nebraska Bureau chief at the Lincoln Journal Star, Dick Ulmer, got into the discussion. "Strunk isn't alone", Ulmer wrote, “in objecting to a term that makes a good 95 percent of Nebraska sound as if it's located somewhere in the trackless wilds of Wyoming”. He mentioned how state Senator Sam Cullan would correct any witness that used outstate while appearing before his legislative committee. If Greater Nebraska took hold, what should they then call the Omaha-Lincoln core? Maybe Lesser Nebraska would gain favor (Ulmer I978). The Nebraska legislature eventually passed a resolution to impose a fine of $\$ 50$ on any state official caught using the words outstate, greater, or lesser in reference to their state (McGinnis 1990).

Minnesota talked about dumping the outstate nomenclature in the r980s, but the editorial staff at the outstate St. Cloud Times thought the controversy was unnecessary: "Pardon us if we're slow to comprehend an insult ...." They noted that outstate had "come into common use, especially in governmental circles" but that "no disparagement seems intended". Anyone thinking such an appellation "derogatory and exclusionary" only needed to see how well "Upstate New York" and "Downstate Illinois" were serving. Some in Minnesota were then suggesting "Greater Minnesota" as a replacement, but the Times editors were thinking "Lesser Minnesota" was not the right way to think of the Twin Cities and suburbs. In the "spirit of fraternal fun", the Times went on to suggest "Higher" (outstate) and "Lower", "Natural" and "Unnatural", "Congenial" and "Congested", or "Bigger" (outstate) and "Smaller" as possible descriptors (St. Cloud Times I987). Citizenry and press still prefer outstate, as a sports columnist argued recently: "You have to get outstate (don't give me that 'Greater Minnesota' nonsense, $\mathrm{OK}$ ?) to find true devotees for the football Gophers" (Reusse 20I6).

\section{Conclusion}

Despite efforts by core residents to put down their peripheral neighbors with negative humor and efforts by the peripherals in some states to do away with the terminology, upstate, downstate, and outstate have served well since at least I 862, I88I, and I900, respectively. These place names convey place baseness in more than a thousand enterprises bearing their imprint. They are the perfect designation for areas not part of a state's core when a commentator wants something less constricting and more inclusive than, say, southern Indiana, northern Florida, or central and western Massachusetts. Exact boundaries of what constitute an upstate, downstate, or outstate segment are unnecessary, and probably unknowable. Of course, as the metropolitan cores of states grow in population 
and territory, the peripheral areas must shrink in size. My feeling, however, is that the words upstate, downstate, and outstate will continue to serve a useful purpose in helping us deal with each state's peripheral other.

Sinatra closed his first broadcast of 1946 by asking listeners to start the year with "a big cup of happiness", "memories of the guys who gave us victory", and the biggest "box of tolerance" they could get. Tolerance seems like a good way to push away from the longstanding conflict between rural and urban USA, between the periphery and the core.

\section{Acknowledgements}

Thanks go to Alec Foster, Mark C. Jones, Bill Kemp, John Kostelnick, Megan Maher, and the anonymous reviewers of the manuscript.

\section{Disclosure statement}

No potential conflict of interest was reported by the author.

\section{Bibliography}

Adam, John. 1908. “Candidate Hughes at Close Range.” Spokane (Washington) Press, Io February I908. Newspapers.com (accessed May 30, 2018).

Albany (Missouri) Ledger. I935. "Grasping at Straws.” 22 August I935. Newspapers.com (accessed January 9, 2019).

Beatrice (Nebraska) Daily Sun. I978. “Guest Editorial: Outstate Nebraska' a Lousy Description.” I3 December I978. Newspapers.com (accessed December 28, 20I 8).

Bergmann, Frank, ed. I985. Upstate Literature: Essays in Memory of Thomas F. O’Donnell. Syracuse: Syracuse University Press.

Brown, Patricia Leigh. 200I. "It's the New Upstate, Way out There." The New York Times, 20 October 200I. ProQuest (accessed August 8, 20I8).

Buckhanon, Kalisha. 2005. Upstate. New York: St. Martin's Press.

Buffalo Evening News. I891. “A Down-state Burglar Arrested.” I2 November I891. Newspapers.com (accessed February I 5,2018 ).

Carmer, Carl. 1966. "Upstate is a Country." In My Kind of Country: Favorite Writings about New York, edited by Carl Carmer, I-I8. New York: David McKay Company.

C. B. A. I93 I. "Out-state." American Speech 6, no. 4: 3 IO-II.

Chicago Daily Herald. I908. "Up to Date.” I6 October I908. Newspapers.com (accessed January 29, 20I8).

Commonwealth v. Carlos Vazquez. 2009. 74 Mass. App. Ct 920. Westlaw (accessed February I3, 20I9).

de Camp, L Sprague. I944. "Pronunciation of Upstate New York Place-Names." American Speech I9, no. 4: $250-65$.

Decatur (Illinois) Herald. I959. "Editorials: Our Opinion." 3 August I959. Newspapers.com (accessed January 8, 2019).

Detroit Free Press. I902. "Stop Stampede for Durand.” 3I July I902. Newspapers.com (accessed February I3, 20I8).

Dunn, Sharon. 2006. "EDAP Changes its Name." Greeley (Colorado) Tribune, 3 February 2006. Google Advanced Search (accessed August 8, 2018).

Ellis, David. I959. “'Upstate Hicks' Versus 'City Slickers'.” New York Historical Society Quarterly 43, no. 2: 202-I9.

Gaffney (South Carolina) Ledger. I90I. “The Gaffney Cotton Mills.” I2 July I90I. Newspapers.com (accessed February 8, 201 8).

Harris, Sullivan D. I862. "Life on the Rail.” Field Notes, 5 April I 862. 
Harris, Sullivan D. I9I. "A Song for Ohio." In Poems on Ohio, edited by C. L. Martzolff, I66. Columbus: Ohio State Archaeological and Historical Society.

Hartford Courant. I901. "Farm and Garden Notes." Io April I901. Newspapers.com (accessed June I3, 20I8).

Hess, Steven. 1987. "From The Hague to The Bronx: Definite Articles in Place Names." Journal of the North Central Name Society Fall I987: I4-22.

Honolulu Advertiser. I970. "Outstanding Opportunity.” 8 February I970. Newspapers.com (accessed May 2I, 20I 8).

Lewis, Sinclair. 1922. Babbitt. New York: Harcourt, Brace and Company.

McDavid, Raven I. Jr. I95 I. "Midland and Canadian Words in Upstate New York." American Speech 26, no. 4: $248-56$.

McGinnis, Lori. I990. "Legislature Bans use of Outstate and Greater Nebraska.” 5 February I990. Google Advanced Search (accessed August I, 20I8).

Macon (Missouri) Republican. I90I. "Missouri Brevities.” I4 December I90I. Newspapers.com (accessed February I9, 2018).

Marshall (Missouri) Republican. I900. "McKinley Re-election.” 9 November I900. Newspapers.com (accessed February 9, 2018).

Mencken, H. L. I977. The American Language: An Inquiry into the Development of English in the United States. $4^{\text {th }}$ ed. New York: Alfred A. Knopf.

Minneapolis Star Tribune. I9I4. "6,000,000 Political Ads Handled by Post Office in June and October.” I November I9 14.” Newspapers.com (accessed May 30, 2018).

Montpelier Vermont Watchman. I 889. “The Grand Army Fair.” 24 July I 889. Newspapers.com (accessed February I 5,2018 ).

Newberry (South Carolina) Weekly Herald. I9I I. "Blease Speaks at Florence.” 7 July I9I I. Newspapers. com (accessed February 8, 20I 8).

Newport (Rhode Island) Mercury. I906. "Naval Reserve Cruise." 25 August 1906. Newspapers.com (accessed May 3I, 20I8).

Newport (Rhode Island) Mercury. I92I. "No New-fangled Notions.” 5 March I92I. Newspapers.com (accessed June 8, 2018).

New York Daily Herald. I875. "Old Executions.” I6 January I875. Newspapers.com (accessed June 6, 20I8).

The New York Times. I 885. "A Collector not Chosen.” 27 June I 885 . ProQuest (accessed May I3, 20I3).

O’Donnell, Thomas Francis. I957. “The Regional Fiction of Upstate New York. PhD. diss.”, Syracuse University.

OED. I989. Oxford English Dictionary. 20 vols. $2^{\text {nd }}$ ed. Oxford: Clarendon.

Ogden (Utah) Standard-Examiner. I939. "Aggies Meet Cougar Team in Hoop Tilt.” 7 January I939. Newspapers.com (accessed January 9, 2019).

Phillips, Betty S. I983. "Upstate and Downstate in New York." Names 3I, no. I: 4I-50.

Ravenna (Ohio) Democratic Press. I877. "Death of Col. Harris.” 3 May I 877. Newspapers.com (accessed January II, 2019).

Remlinger, Kathryn A. 2017. Yooper Talk: Dialect as Identity in Michigan's Upper Peninsula. Madison: The University of Wisconsin Press.

Reusse, Patrick. 2016. "Country is why we love 'Country Jer.” Minneapolis Star Tribune. I I September 2016. Newspapers.com (accessed December 28, 2018).

St. Cloud (Minnesota) Times. 1987. "If not 'Outstate', then 'Higher Minnesota'." 25 February 1987. Newspapers.com (accessed December 28, 2018).

St. Paul (Kansas) Journal. I902. "Troubles of Young Housewives." I9 June I902. Newspapers.com (accessed February I 5, 2018).

Salt Lake Tribune. 1908a. "Out upon the Filthy Frauds!" 6 April 1908. Newspapers.com (accessed June I 2, 2018).

Salt Lake Tribune. I908b. "Visiting Teachers to be Entertained." 29 November 1908. Newspapers.com (accessed February I3, 2018).

Seibel, Paul. 1966. "Fore and Aft." Sayre (Pennsylvania) Evening Times, 7 February 1966. Newspapers. com (accessed January 9, 2019).

Simon, Stephanie. 2004. "Democrats Scramble in up-for-grabs Missouri." Twin Falls (Idaho) Times-News, I February 2004. Newspapers.com (accessed May I8, 20I8). 
Sinatra, Frank. I946. "Songs by Sinatra.” Radio program recorded 2 January 1946 in New York, New York. https://otrr.org/index.html (accessed February 22, 2019).

Stewart, George R. [1945] 2008. Names on the Land: A Historical Account of Place-naming in the United States. New York: New York Review of Books.

Sublett, Michael D. 2016. “'Downstate: Illinois' Peripheral Other.” Journal of the Illinois State Historical Society 109, no. 3: 300-28.

Sufrin, Sidney C., et al. 1960. The Economic Status of Upstate New York at Mid-century with Special Reference to Distressed Communities and their Adjustments. Syracuse: Business Research Center, Syracuse University.

Thomas, C. K. I935. "Pronunciation in Upstate New York." American Speech Io, no. 2: I07-I 2.

Ulmer, Dick. 1978. "Outstate Folks in State of Despair: 'Greater Nebraska' Tag not Theirs." Lincoln Journal Star, 27 December I978. Newspapers.com (accessed December 28, 2018).

Urbana (Ohio) Union. I 862. "Life on the Rail." 23 April I 862. Newspapers.com (accessed June 6, 2018).

US Army. Corps of Engineers. I963. "New England Division.” Public Affairs Office. In The Work of the U.S. Army Corps of Engineers in Rhode Island. Washington, DC: GPO.

Vandergrift, K. S. I943. "Schofield Red Dust." Honolulu Advertiser, I2 April I943. Newspapers.com (accessed June 4, 20I8).

Vorva, Jeff. 2013. "Athlete Overcomes Hurdles to Compete in High Jump." Chicago Tribune, 30 May 20I3. ProQuest (accessed March II, 20I4).

Wilmington (Delaware) Morning News. I 88I. "Down the State." 25 July I 88I. Newspapers.com (accessed February I 5, 2018).

Wilson, Edmund. I97I. Upstate: Records and Recollections of Northern New York. New York: Farrar, Straus, and Giroux.

Yorkville (South Carolina) Enquirer. I909. "Marketing a New Product.” 7 May I909. Newspapers.com (accessed February I9, 2018).

\section{Notes on contributor}

A professor emeritus, Michael D. Sublett served on the faculty at Illinois State University from 1970 to 2015 and chaired the Department of GeographyGeology from 1978 to 1988 . His degrees, all in Geography, include the B.A. (Phi Beta Kappa) and M.A. from the University of Missouri-Columbia and the Ph.D. from the University of Chicago. His research has focused recently on toponyms in the United States. (D) http://orcid.org/oooo-ooor-6896-9940

Correspondence to: Michael D. Sublett Department of Geography, Geology, and the Environment, Illinois State University, Campus Box 4400, Normal, IL 6I790-4400, USA. E-mail: mdsuble@ilstu.edu 